\title{
Flavonol Tri-O-glycoside and Other Chemical Constituents from Flowers of Aristolochia trulliformis
}

\author{
Juliana C. Holzbach, ${ }^{a}$ Walter A. Soares Filho, ${ }^{a}$ Camila L. Cunha ${ }^{a}$ and \\ Isabele R. Nascimento ${ }^{\circledR} *, a$ \\ anstituto de Química, Universidade Estadual Paulista (Unesp), \\ CP 355, 14800-060 Araraquara-SP, Brazil
}

\begin{abstract}
A new flavonol triglycoside, named kaempferol-3-O- $\beta$-D-glucopyranosyl$(1 \rightarrow 4)$ - $\alpha$-L-rhamnopyranosyl- $(1 \rightarrow 6)-\beta$-D-glucopyranoside, was isolated from flowers of Aristolochia trulliformis (Aristolochiaceae) together with 15 known compounds, including six flavonoids and four lignans. The structures of the compounds were determined by spectroscopic analyses, including 1D and 2D nuclear magnetic resonance (NMR) techniques and high-resolution mass spectrometry (HRMS).
\end{abstract} lignans

Keywords: Aristolochia trulliformis, Aristolochiaceae, flavonoids, kaempferol triglycoside,

\section{Introduction}

Aristolochia is the largest genus of the Aristolochiaceae family with about 550 species worldwide and 38 endemic species to Brazil. ${ }^{1,2}$ Aristolochia species are known as "Dutchman's pipe", "birthwort", and "pipe vine", and are recognized for their use in traditional medicine for being abortifacients, antiophidics, stomachics, antiinflammatories, antiasthmatics, expectorants, antiseptics, sedatives, and for their use in slimming therapies. ${ }^{3}$ The Aristolochia plants are also recognized to cause aristolochic acid nephropathy, a disease associated with kidney failure and upper urothelial carcinoma. ${ }^{4}$

Aristolochia spp. are also known for their peculiar flowers, specialized in trapping, retaining, and releasing pollinators. The pollination biology of Aristolochia species, in which the pollinators are attracted by deception, has been studied for more than two centuries. ${ }^{5}$ In this pollinating system, the attraction is carried out by imitation of mating partners, or of food sources, or sites for oviposition by structural, visual, or scent signals related to the production of special metabolites in flowers. ${ }^{6,7}$ Recently, Oelschlägel et al. ${ }^{7}$ proposed a new mimicry system of pollination, called kleptomyiophily, based on studies using A. rotunda. It was demonstrated that the flowers mimic the scent released by freshly dead insects to deceive and attract their pollinators which are searching a food source.

*e-mail: isabele.nascimento@unesp.br
Even with these interesting floral and pollination characteristics, few species of Aristolochia had the chemical composition of their floral scent analysed by gas chromatography-mass spectrometry (GC-MS). Flowers of A. gigantea female stage emitted a sweet lemon-scented terpenoids, including (E)-citral (geranial), (Z)-citral (neral), citronellal, citronellol, nerol, and geraniol, and at the same time smaller amounts of pungent, brood-site associated volatiles such as dimethyl disulfide, 2-heptanone, and 3-methyl-1-butanol. At the male phase of development, the volatile emission of A. gigantea flowers was highly reduced for the novel production of linalool, $(Z, E)-\alpha$ - and $(E, E)$ - $\alpha$-farnesene, and their oxygenated derivatives. ${ }^{8}$ The fetid floral scent of A. cymbifera contained high relative amounts of aromatic esters (benzyl propionate, benzyl isovalerate, benzyl butanoate, benzyl pentanoate), sulfur compounds (dimethyl disulfide, dimethyl trisulfide), $p$-cresol, and indole. ${ }^{9}$ A. ringens fetid flowers were composed mainly of terpenes normally found in essential oils and compounds of known unpleasant odor, such as undecanal, nonanal, decanal, and 2-methylbutanoic acid. ${ }^{10}$ A. rotunda floral scent presented aliphatic hydrocarbons and aliphatic esters. ${ }^{7}$

Whereas phytochemical studies involving stems, leaves and roots of Aristolochia plants are usually found in the literature, ${ }^{3,11,12}$ there are only two studies on the isolation and structural elucidation of compounds from flowers. From fresh flowers of A. kaempferi, there were isolated flavonol diglycosides, steroids, asparagine, and aristolochic 
acid derivatives, including a denitro-aristolochic acid glycoside $;{ }^{13}$ and from a mixture of fresh flowers and fruits of A. zollingeriana, $\mathrm{Wu}$ and co-workers ${ }^{14}$ isolated aristolochic acid derivatives, phenols, and steroids.

The aim of this study was the isolation and structural elucidation of the main compounds present in A. trulliformis flowers. This species is found in Brazilian Cerrado biome and has greenish flowers with an inconspicuous scent.

\section{Results and Discussion}

Dried flowers of A. trulliformis were extracted with<smiles>[R]c1cc(-c2oc3cc(O)cc(O)c3c(=O)c2[R])ccc1O</smiles><smiles>[R][R]</smiles>

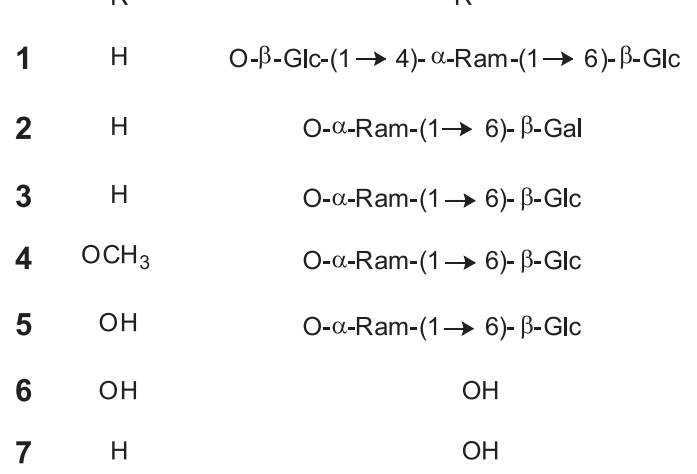<smiles>[R]c1ccc(CC2(Cc3ccc([R])c([R])c3)COC([R])[C@H]2C)cc1[R]</smiles>

$\begin{array}{cccccc} & \mathrm{R}^{1} & \mathrm{R}^{2} & \mathrm{R}^{3} & \mathrm{R}^{4} & \mathrm{R}^{5} \\ 13 & =\mathrm{O} & \mathrm{OCH}_{3} & \mathrm{OCH}_{3} & \mathrm{OCH}_{3} & \mathrm{OCH}_{3} \\ 14 & =\mathrm{O} & \mathrm{OCH}_{2} \mathrm{O} & \mathrm{OCH}_{3} & \mathrm{OCH}_{3} \\ 15 & =\mathrm{O} & \mathrm{OCH}_{2} \mathrm{O} & \mathrm{OCH}_{2} \mathrm{O} \\ 16 & \mathrm{OH} & \mathrm{OCH}_{2} \mathrm{O} & \mathrm{OCH}_{2} \mathrm{O}\end{array}$

$\mathrm{MeOH}$. The concentrated extract presented a sweet scent and the ${ }^{1} \mathrm{H}$ nuclear magnetic resonance (NMR) analysis suggested the occurrence of a high amount of sugars and cyclitols. In order to separate these classes of compounds, the extract was subjected to Amberlite XAD-16 eluting with $\mathrm{H}_{2} \mathrm{O}, \mathrm{MeOH}$ and EtOAc, successively. ${ }^{1} \mathrm{H}$ NMR analysis of the aqueous portion (4.9 g, ca. 70\%) showed mainly sugars and cyclitols. The $\mathrm{MeOH}$ and EtOAc portions were subjected to column chromatography (CC), followed by semi-preparative high-performance liquid chromatography (HPLC) purification to afford sixteen compounds (1-16, Figure 1), including a new flavonol triglycoside (1).<smiles>O=C1CC[C@H]2c3cc(O)c(O)cc3CCN12</smiles><smiles>COCCc1ccccc1</smiles><smiles>O=C(O)c1ccc(O)cc1</smiles>

10<smiles>O=C(O)/C=C/c1ccc(O)cc1</smiles><smiles>O=C(O)/C=C\c1ccc(O)cc1</smiles>

12

Figure 1. Chemical constituents from flowers of Aristolochia trulliformis Mast. 
Compound 1 showed the typical maximum absorption at 265 and $345 \mathrm{~nm}$ as reported for kaempferol glycosides. ${ }^{15}$ High-resolution mass spectrometry (HRMS) analysis showed $[\mathrm{M}-\mathrm{H}]^{-}$ion at $\mathrm{m} / z \mathbf{z} 755.2065$ for deprotonated molecule, indicating the molecular formula $\mathrm{C}_{33} \mathrm{H}_{40} \mathrm{O}_{20}$ (calcd. for $\mathrm{C}_{33} \mathrm{H}_{39} \mathrm{O}_{20}, 755.2035$ ). MS/MS analysis of the peak at $m / z 755$ showed the major product ion at $\mathrm{m} / \mathrm{z}, 285$ (kaempferol aglycone) due to loss of two hexoses (162 Da each) and one methyl-pentose (146 Da) moieties. The MS/MS spectra of $\mathbf{1}$ exhibited the observed pattern for flavonol 3-O-triglycosides. ${ }^{16}$ To confirm the structure of the aglycone portion and to identify the sugar moieties, 1D and 2D NMR experiments were performed. The ${ }^{1} \mathrm{H}$ NMR spectrum showed two typical proton signals of a 5,7-substituted flavonol A-ring $\left(\delta_{\mathrm{H}} 6.21, \mathrm{~d}, J 2.1 \mathrm{~Hz}\right.$, H-6 and $\left.\delta_{\mathrm{H}} 6.46, \mathrm{~d}, J 2.1 \mathrm{~Hz}, \mathrm{H}-8\right)$ and two doublets of a 1,4-disubstituted monoxigenated system on B-ring $\left(\delta_{\mathrm{H}} 8.08, \mathrm{~d}, J 8.9 \mathrm{~Hz}, \mathrm{H}-2^{\prime}, 6^{\prime}\right.$ and $\delta_{\mathrm{H}} 6.91, \mathrm{~d}, J 8.9 \mathrm{~Hz}$, H-3', 5'), confirming kaempferol as the aglycone (Table 1). The three doublets at $\delta_{\mathrm{H}} 4.50$ (d, J $1.4 \mathrm{~Hz}, \mathrm{H}-1$ '”'), 4.52 (d, $J 7.8 \mathrm{~Hz}, \mathrm{H}-1$ '"'), and 5.17 (d, $J 7.5 \mathrm{~Hz}, \mathrm{H}-1$ ") assigned the presence of three anomeric protons. The selective irradiation of anomeric protons at $\delta_{\mathrm{H}} 5.17$ and 4.52 in the 1D-TOCSY (total correlation spectroscopy) experiments displayed the spin systems of the glucose units, whereas the irradiation at the methyl group at $\delta_{\mathrm{H}} 1.13$ suggested the spin system of the rhamnose unit. The identity of the glycoside units were confirmed by the correlations observed in the heteronuclear single quantum correlation (HSQC) experiment. The $\beta$ - and $\alpha$-configuration of the glucopyranosyl and rhamnopyranosyl units, respectively, were deduced from the magnitude of the coupling constants of the anomeric protons. The hydrogens H-1" and $\mathrm{H}-1$ '"' of glucose units presented coupling constants of 7.5 and $7.8 \mathrm{~Hz}$, respectively, indicating that both have $\beta$ configuration, whereas $\mathrm{H}-1$ "' of the rhamnose unit presented a coupling constant of $1.4 \mathrm{~Hz}$, suggesting an $\alpha$ configuration.

2D NMR experiments were performed to determine the trisaccharide residue sequence. HSQC and heteronuclear multiple bond correlation (HMBC) spectra displayed important correlations between hydrogens and carbons of $\mathbf{1}$ (Figure 2), mainly of H-1"' $\left(\delta_{\mathrm{H}} 4.50\right)$ and C-6" $\left(\delta_{\mathrm{C}} 68.2\right)$ denoting a $1 \rightarrow 6$ linkage between the rhamnose and one of the glucose unit. Correlations between C-4"' $\left(\delta_{\mathrm{C}} 83.2\right)$ of the rhamnose and H-6"' $\left(\delta_{\mathrm{H}} 1.13\right)$ and the anomeric proton $\mathrm{H}-1$ "' $\left(\delta_{\mathrm{H}} 4.52\right)$ of the glucose residue indicated that the another glucose unit is linked at C-4" " of rhamnose. The downfield chemical shift of C-4"' ( $\Delta \delta$ ca. $10 \mathrm{ppm})$ is expected when glycosylation occurs at this position. ${ }^{17}$ The linkage between the trisaccharide and the aglycone at $\mathrm{C}-3$
Table 1. NMR data for compound $\mathbf{1}\left(14.1 \mathrm{~T}, \delta\right.$ in ppm, $J$ in $\left.\mathrm{Hz}, \mathrm{CD}_{3} \mathrm{OD}\right)$

\begin{tabular}{|c|c|c|c|}
\hline Position & $\delta_{C}{ }^{a}$ & $\delta_{\mathrm{H}}$ & HМBC \\
\hline 2 & 157.9 & - & H-2', 6', \\
\hline 3 & b & - & \\
\hline 4 & b & - & \\
\hline 5 & 162.3 & - & H-6 \\
\hline 6 & 99.7 & $6.21(\mathrm{~d}, J 2.1)$ & H-8 \\
\hline 7 & 165.9 & - & H-8 \\
\hline 8 & 94.5 & $6.46(\mathrm{~d}, J 2.1)$ & H-6 \\
\hline $8 \mathrm{a}$ & 158.0 & - & $\mathrm{H}-8$ \\
\hline $4 a$ & 105.2 & - & $\mathrm{H}-8,6$ \\
\hline 1 ' & 122.5 & - & H-3', 5, \\
\hline $2^{\prime}$ and 6' & 132.2 & $8.08(\mathrm{~d}, J$ 8.9) & H-3', 5' \\
\hline $3^{\prime}$ and $5^{\prime}$ & 116.0 & $6.91(\mathrm{~d}, J 8.9)$ & H-2', 6' \\
\hline $4^{\prime}$ & 160.7 & - & H-2', 6', 3', 5' \\
\hline \multicolumn{4}{|l|}{ Glucose } \\
\hline $1 "$ & 103.7 & $5.17(\mathrm{~d}, J 7.5)$ & \\
\hline 2" & 74.8 & $3.24-3.43(\mathrm{~m})$ & H-4", 3" \\
\hline $3 "$ & 77.6 & $3.24-3.43(\mathrm{~m})$ & $\mathrm{H}-4 "$ \\
\hline 4" & 71.1 & $3.24-3.43(\mathrm{~m})$ & H-6" \\
\hline $5 "$ & 77.3 & $3.24-3.43(\mathrm{~m})$ & $\mathrm{H}-3 "$ \\
\hline \multirow[t]{2}{*}{ 6" } & 68.2 & 3.78 (br d, $J 10.9$ ) & H-1"” \\
\hline & & $3.24-3.43(\mathrm{~m})$ & \\
\hline \multicolumn{4}{|c|}{ Rhamnose } \\
\hline $1 "$, & 102.0 & $4.50(\mathrm{~d}, J 1.4)$ & \\
\hline $2 "$ & 71.7 & $3.24-3.72(\mathrm{~m})$ & $\mathrm{H}-1 "$, \\
\hline $3 "$, & 71.5 & $3.24-3.72(\mathrm{~m})$ & \\
\hline $4 "$, & 83.2 & $3.45-3.47(\mathrm{~m})$ & H-1"', 2"', 6", \\
\hline $5 "$ & 68.0 & $3.45-3.47(\mathrm{~m})$ & H-4"', 6"' \\
\hline $6 "$ & 17.6 & $1.13(\mathrm{~d}, J 5.7)$ & \\
\hline \multicolumn{4}{|l|}{ Glucose } \\
\hline $1 " ”$ & 105.4 & $4.52(\mathrm{~d}, J 7.8)$ & H-4"”, 3"'” \\
\hline $2 " ”$ & 75.8 & $3.24-3.43(\mathrm{~m})$ & $\mathrm{H}-4$ "”, \\
\hline 3"”' & 77.6 & $3.24-3.43(\mathrm{~m})$ & H-2,"' \\
\hline 4"”' & 71.1 & $3.24-3.43(\mathrm{~m})$ & H-3"'” \\
\hline $5 " ”$ & 77.2 & $3.24-3.43(\mathrm{~m})$ & \\
\hline \multirow[t]{2}{*}{$6 " ”$} & 62.3 & 3.85 (br d, $J 10.2)$ & $\mathrm{H}-4, "$, \\
\hline & & $3.67-3.70(\mathrm{~m})$ & \\
\hline
\end{tabular}

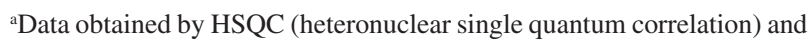
HMBC (heteronuclear multiple bond correlation); bsignal not observed.

was determined based on the comparison of the ${ }^{13} \mathrm{C}$ NMR data of $\mathbf{1}$ and kaempferol, ${ }^{18}$ including the chemical shift of C-2 position $\left(\delta_{\mathrm{C}} 157.9\right.$ for 1 , and $\delta_{\mathrm{C}} 148.0$ for kaempferol).

The configurations of glucose and rhamnose moieties were considered to belong to D- and L-series, respectively, as these are the isomers usually found in plants. ${ }^{19}$ 


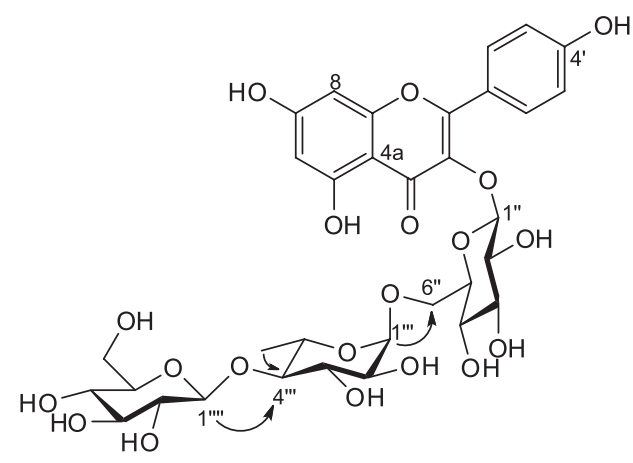

Figure 2. Select HMBC correlations of compound $\mathbf{1}$.

Therefore, compound $\mathbf{1}$ was unambiguously determined as kaempferol-3-O- $\beta$-D-glucopyranosyl- $(1 \rightarrow 4)-\alpha$-Lrhamnopyranosyl-( $1 \rightarrow 6)-\beta$-D-glucopyranoside.

The structures of the known compounds (2-16) were determined by comparison of their physical and spectroscopic data with those of authentic samples and/or reported data in the literature. The known compounds were identified as kaempferol-3-O-robinobioside (2), ${ }^{20}$ kaempferol3-O-rutinoside (3), ${ }^{21}$ isorhamnetin-3-O-rutinoside (4), ${ }^{22}$ rutin $(\mathbf{5}),{ }^{23}$ quercetin $(\mathbf{6})$, kaempferol (7), ${ }^{18}(-)$-trolline $(\mathbf{8}),{ }^{24}$ 2-phenylethyl- $\beta$-glucopyranoside $(\mathbf{9}),{ }^{25} p$-hydroxybenzoic acid (10), cis- (11) and trans-p-coumaric acid (12), ${ }^{26}$ (-)-methylarctigenin $(\mathbf{1 3}),{ }^{27}(-)$-kusunokinin $(\mathbf{1 4}),{ }^{28}$ $(-)$-hinokinin (15), ${ }^{29}$ and (-)-cubebin (16) ${ }^{30}$

\section{Conclusions}

This study contributed to the knowledge of the chemical constituents of the Aristolochia genus, once there are only two published studies on the isolation and the structural elucidation of compounds from flowers of these plants. Seven flavonol derivatives, four lignans, one alkaloid, and four $\mathrm{C}_{6}-\mathrm{C}_{\mathrm{n}}$ derivatives were isolated from flowers of A. trulliformis. The flavonol triglycoside $\mathbf{1}$ is being described for the first time in the literature. This is also the first report about the isolation of lignans from flowers of Aristolochia. No aristolochic acid derivative was detected in flowers of A. trulliformis.

\section{Experimental}

\section{General experimental procedures}

One-dimensional $\left({ }^{1} \mathrm{H},{ }^{13} \mathrm{C}\right.$, and TOCSY $)$ and two-dimensional $\left({ }^{1} \mathrm{H}-{ }^{1} \mathrm{H}\right.$ correlation spectroscopy (COSY), HSQC, and HMBC) NMR experiments were performed on a Bruker Avance III 600 spectrometer (14.1 T) at 600 $\left({ }^{1} \mathrm{H}\right)$ and $151 \mathrm{MHz}\left({ }^{13} \mathrm{C}\right)$ using deuterated solvents $\left(\mathrm{CDCl}_{3}\right.$, $\mathrm{CD}_{3} \mathrm{OD}$, and DMSO- $\left.d_{6}\right)(99.98 \% \mathrm{D})$ as internal standards for ${ }^{13} \mathrm{C}$ NMR chemical shifts and residual solvent as an internal standard for ${ }^{1} \mathrm{H}$ NMR. $\delta$ values are reported relative to $\mathrm{Me}_{4} \mathrm{Si}$. High-resolution mass spectra were obtained on a Q-TOF Bruker MaXis Impact ${ }^{\mathrm{TM}}$ mass spectrometer. Optical rotations were measured on a PerkinElmer 341-LC polarimeter. HPLC analyses were performed using a Jasco LC-NetII/ADC liquid chromatograph, equipped with photodiode array (MD-2018 Plus) and CD (2095 Plus) detectors. HPLC-solid phase extractiontransfer tube (HPLC-SPE-TT) analyses were carried out on a Bruker system composed of an Agilent Series 1260 liquid chromatograph using a photodiode array detector (G1315D), a Spark Prospekt 2 solid phase extraction unit, a make-up pump (Knauer), and a Gilson liquid handler 215. HySphere ${ }^{\mathrm{TM}}$ polydivinylbenzene-resin-filled SPE cartridges $(5-15 \mu \mathrm{m})$ were used to trap resolved peaks from fractions. Cartridges were dried with $\mathrm{N}_{2}$ gas and eluted with $\mathrm{CD}_{3} \mathrm{OD}$ for a further NMR analysis in $3 \mathrm{~mm}$ NMR tubes. Zorbax RX C18 columns ( $5 \mu \mathrm{m}, 9.4 \times 250 \mathrm{~mm}$ and $5 \mu \mathrm{m}$, $4.6 \times 250 \mathrm{~mm}$, Agilent) were used for semi-preparative and analytical analysis. Solvents employed were HPLC grade from Mallinckrodt. Ultrapure water was obtained from Direct-Q3 UV System from Millipore.

\section{Plant material}

The flowers of A. trulliformis Mast. were collected in Gurupi, TO, Brazil, in August-December 2015 and identified by MSc Joelcio Freitas. A voucher specimen (MBML 50516) was deposited at the herbarium of Museu de Biologia Prof Mello Leitão (MBML), Santa Teresa, ES, Brazil.

\section{Extraction and isolation}

The flowers of A. trulliformis were dried (22.5 g), ground and extracted with methanol $(4 \times 80 \mathrm{~mL}, 24 \mathrm{~h}$ each). The solvent was removed under reduced pressure. The extract $(7.0 \mathrm{~g})$ was fractionated on Amberlite XAD-16 column $(2.0 \times 29.0 \mathrm{~cm})$ eluting with $\mathrm{H}_{2} \mathrm{O}(1000 \mathrm{~mL})$, $\mathrm{MeOH}(500 \mathrm{~mL})$ and EtOAc $(600 \mathrm{~mL})$, successively. The $\mathrm{MeOH}$ portion was concentrated $(1.0 \mathrm{~g})$ and subjected to $\mathrm{CC}$ (Sephadex LH-20, $1.0 \times 30.0 \mathrm{~cm}, \mathrm{MeOH}$ ) to give 12 fractions (ca. $20 \mathrm{~mL}$ each; Fr 1-Fr 12). Fr 4 was purified by semi-preparative $\mathrm{HPLC}\left(\mathrm{MeOH} / \mathrm{H}_{2} \mathrm{O}\right.$ $20 \rightarrow 50 \% \mathrm{MeOH}$, flow rate $2.5 \mathrm{~mL} \mathrm{~min}^{-1}, 50 \mathrm{~min}$ ) to yield $\mathbf{1}(1.4 \mathrm{mg}), \mathbf{2}(2.4 \mathrm{mg}), \mathbf{3}(16.9 \mathrm{mg}), \mathbf{3}+\mathbf{4}(2.5 \mathrm{mg})$, $\mathbf{5}(7.9 \mathrm{mg}), \mathbf{9}+\mathbf{1 1}+\mathbf{1 2}(6.0 \mathrm{mg})$, and $\mathbf{8}+\mathbf{1 0}(6.7 \mathrm{mg})$. Fr 8 was subjected to C18 LC-SPE-TT using $\mathrm{ACN} / \mathrm{H}_{2} \mathrm{O} 5 \rightarrow 64 \% \mathrm{ACN}$, flow rate $1.0 \mathrm{~mL} \mathrm{~min}^{-1}$ in $25 \mathrm{~min}$ to give $6(0.3 \mathrm{mg})$ and $7(0.5 \mathrm{mg})$. Fr 9 gave $6(5.2 \mathrm{mg})$. 
The EtOAc portion $(310.0 \mathrm{mg})$ was fractioned by $\mathrm{CC}$ on silica gel $(1.0 \times 18.5 \mathrm{~cm})$ eluting with Hex/EtOAc gradient (9:1 Hex/EtOAc to $100 \%$ EtOAc) to yield eleven fractions (ca. $15 \mathrm{~mL}$ each; Fr A-Fr K). Fr J was subjected to semipreparative $\mathrm{HPLC}\left(\mathrm{ACN} / \mathrm{H}_{2} \mathrm{O} 40 \rightarrow 100 \% \mathrm{ACN}\right.$, flow rate $\left.2.5 \mathrm{~mL} \mathrm{~min}^{-1}, 50 \mathrm{~min}\right)$ to yield $\mathbf{1 3}(1.2 \mathrm{mg}), \mathbf{1 4}(1.0 \mathrm{mg})$, $\mathbf{1 5}(1.0 \mathrm{mg})$, and $\mathbf{1 6}(1.1 \mathrm{mg})$.

Kaempferol-3-O- $\beta$-D-glucopyranosyl-( $1 \rightarrow 4)$ - $\alpha$-L-rhamnopyranosyl-( $1 \rightarrow 6)-\beta$-D-glucopyranoside (1)

White amorphous powder; ${ }^{1} \mathrm{H}$ and ${ }^{13} \mathrm{C}$ NMR data, see Table 1; HRMS (electrospray ionization-quadrupole time of flight (ESI-(-)-QTOF) $\mathrm{m} / z$ (rel. int.): 755.2065 [M - H] ${ }^{-}$ (100) (calcd. for $\mathrm{C}_{33} \mathrm{H}_{39} \mathrm{O}_{20}, 755.2035$, error $+4.0 \mathrm{ppm}$ ).

\section{Supplementary Information}

Supplementary information is available free of charge at http://jbcs.org.br as PDF file.

\section{Acknowledgments}

The authors thank MSc Joelcio Freitas for plant identification, and FAPESP, CAPES, and CNPq for financial support and fellowships.

\section{References}

1. González, F.; Rev. Acad. Colomb. Cienc. Exactas, Fis. Nat. 2012, 36, 193.

2. http://reflora.jbrj.gov.br/reflora/floradobrasil/FB54, accessed in August 2018.

3. Lopes, L. M. X.; Nascimento, I. R.; da Silva, T.; Res. Adv. Phytochem. 2001, 2, 19.

4. Jadot, I.; Declèves, A. E.; Nortier, J.; Caron, N.; Int. J. Mol. Sci. 2017, 18, 297.

5. Berjano, R.; Ortiz, P. L.; Arista, M.; Talavera, S.; Plant Biol. 2009, 11, 6 .

6. Erbar, C.; Heiler, A.; Leins, P.; Flora 2017, 232, 128.

7. Oelschlägel, B.; Nuss, M.; von Tschirnhaus, M.; Patzold, C.; Neinhuis, C.; Dotterl, S.; Wanke, S.; New Phytol. 2015, 206, 342.

8. Martin, K. R.; Moré, M.; Hipólito, J.; Charlemagne, S.; Schlumpberger, B. O.; Raguso, R. A.; Flora 2017, 232, 153.

9. Johnson, S. D.; Jürgens, A.; S. Afr. J. Bot. 2010, 76, 796.

10. Stashenko, E. E.; Ordonez, S. A.; Marin, N. A.; Martinez, J. R.; J. Chromatogr. Sci. 2009, 47, 817.
11. Wu, T. S.; Amooru, D. G.; Chung-Ren, S.; Ping-Chung, K. In Studies in Natural Products Chemistry, vol. 32; Atta-urRahman, ed.; Elsevier: Amsterdam, 2005, p. 855.

12. Michl, J.; Ingrouille, M. J.; Simmonds, M. S.; Heinrich, M.; Nat. Prod. Rep. 2014, 31, 676.

13. Wu, T. S.; Leu, Y. L.; Chan, Y. Y.; Phytochemistry 1998, 49, 2509.

14. Chiang, C. Y.; Leu, Y. L.; Chan, Y. Y.; Wu, T. S.; J. Chin. Chem. Soc. 1998, 45, 93.

15. Jang, G. H.; Kim, H. W.; Lee, M. K.; Jeong, S. Y.; Bak, A. R.; Lee, D. J.; Kim, J. B.; Saudi J. Biol. Sci. 2018, 25, 1622.

16. Qin, Y.; Gao, B.; Shi, H.; Cao, J.; Yin, C.; Lu, W.; Yu, L.; Cheng, Z.; J. Pharm. Biomed. Anal. 2017, 142, 113.

17. Liu, X.; Ye, W.; Yu, B.; Zhao, S.; Wu, H.; Che, C.; Carbohydr. Res. 2004, 339, 891.

18. Kipchakbaeva, A. K.; Khamid, R. A.-A.; Eskalieva, B. K.; Burasheva, G. S.; Abilov, Z. A.; Numonov, S. R.; Aisa, H. A.; Chem. Nat. Compd. 2016, 52, 322.

19. Robyt, J. F.; Essentials of Carbohydrate Chemistry, $1^{\text {st }}$ ed.; Springer: New York, 1998.

20. Song, J. L.; Yang, Y. J.; Qi, H. Y.; Li, Q.; J. Chin. Med. Mater. 2013, 36, 752 .

21. de Sousa, E. A.; da Silva, A. A. C. A.; Cavalheiro, A. J.; Lago, J. H. G.; Chaves, M. H.; J. Braz. Chem. Soc. 2014, 25, 704.

22. Lee, E. H.; Kim, H. J.; Song, Y. S.; Jin, C.; Lee, K. T.; Cho, J.; Lee, Y. S.; Arch. Pharmacal Res. 2003, 26, 1018.

23. Chang, Y.; Zhang, P.; Zhang, X.; Chen, J.; Rausch, W. D.; Gula, A.; Bao, B.; Nat. Prod. Res. 2017, 31, 1223.

24. Kawai, N.; Matsuda, M.; Uenishi, J. I.; Tetrahedron 2011, 67, 8648.

25. Piao, M. S.; Kim, M.-R.; Lee, D. G.; Park, Y.; Hahm, K.-S.; Moon, Y.-H.; Woo, E.-R.; Arch. Pharmacal Res. 2003, 26, 453.

26. Zhu, L.; Lei, N.; Miao, Z.; Sheng, C.; Zhuang, C.; Yao, J.; Zhang, W.; Chin. J. Chem. 2012, 30, 139.

27. Chimichi, S.; Cosimelli, B.; Bambagiotti-Alberti, M.; Coran, S. A.; Vincieri, F. F.; Magn. Reson. Chem. 1993, 31, 1044.

28. Lopes, L. M. X.; Yoshida, M.; Gottlieb, O. R.; Phytochemistry 1983, 22, 1516.

29. Heleno, V. C. G.; da Silva, R.; Pedersoli, S.; de Albuquerque, S.; Bastos, J. K.; Silva, M. L. A.; Donate, P. M.; da Silva, G. V. J.; Lopes, J. L. C.; Spectrochim. Acta, Part A 2006, 63, 234.

30. de Pascoli, I. C.; Nascimento, I. R.; Lopes, L. M. X.; Phytochemistry 2006, 67, 735.

Submitted: August 30, 2018 Published online: December 14, 2018 